\title{
Publication Trend of R\&D in the Journal of Biological Education in Indonesia (Sinta 2: 2017-2021): A Systematic Literature Review
}

\author{
*Abdulkadir Rahardjanto, Husamah \\ Biology Education Department, Faculty of Teacher Training and Education, Universitas \\ Muhammadiyah Malang. Jl. Raya Tlogomas 246 Malang, East Java, 65144, Indonesia \\ *Corresponding Author e-mail: abdkadir@umm.ac.id
}

Received: January 2022; Revised: January 2022; Published: January 2022

\begin{abstract}
Research on R\&D in education is still very much needed. This systematic literature review (SLR) was aimed to analyze the trend of publications in the field of R\&D in the journal of biological education in Indonesia. The results of this SLR will illustrate the condition of R\&D publications until 2021, both in terms of quantity, quality, and contribution. This systematic literature review adopts five-step guidelines from Denyer and Tranfield. Based on the study results, it can be seen that journals in the field of biology education have published a total of 379. JPBI has published the most articles, as many as 206 articles. Specifically, in the field of $R \& D$, JPBI has published 37 articles on R\&D. This shows a good contribution to the development of science and technology, especially in terms of products produced by R\&D. There are 9 models used, and the dominant ones used are 3D Thiagarajan, ADDIE, and Borg \& Gall. In general, $61 \%$ of articles do not consistently carry out the stages of the R\&D model used. The dominant keyword used is "Education". These keywords are often used in conjunction with several other keywords. The results show that R\&D has been widely used to develop products that support education. Most of the R\&D carried out by experts is focused on high school and college levels, which are $45 \%$ and $40 \%$, respectively.
\end{abstract}

Keywords: research and development, R\&D, biological education, higher education

How to Cite: Rahardjanto, A., \& Husamah, H. (2022). Publication trend of R\&D in the journal of biological education in Indonesia (Sinta 2: 2017-2021): A systematic literature review. Prisma Sains : Jurnal Pengkajian Ilmu dan Pembelajaran Matematika dan IPA IKIP Mataram, 10(1), 21-35. doi:https://doi.org/10.33394/jps.v10i1.4769

https://doi.org/10.33394/j-ps.v10i1.4769

Copyright $\odot$ 2022, Rahardjanto \& Husamah This is an open-access article under the CC-BY License. (c) (i)

\section{INTRODUCTION}

Research and Development (R\&D), is a form of research that is innovative, productive, and meaningful (Haviz, 2016), generally now widely used in the world of education (Hidayat, 2018). $R \& D$ is oriented to produce innovative works that are very useful for their respective educational institutions (Zuriyani, 2014). R\&D refers to innovative activities undertaken to develop new services or products or improve existing services or existing products. R\&D is the first stage of developing a potential new service or production process (Embedded Artistry, 2022). Since the 1980s, the R\&D method was coined out by Borg and Gall as a model design for educational research (Gustiani, 2019).

$\mathrm{R} \& \mathrm{D}$ is a process used to develop and validate educational products (Borg \& Gall, 1983). R\&D is a systematic study of the process of designing, developing, and evaluating "interventions" (programs, teaching and learning strategies and their tools, products, and systems) as solutions to complex problems in practical education, and also has the aim of increasing knowledge about characteristics of the "intervention" and the design and development process (Gay et al., 2009; Plomp, 2007; Richey \& Klein, 2007). Productoriented R\&D that is widely used in education(Borg \& Gall, 2003) and the improvement of 
education quality as it is connected to the evaluation program in the education domain (Gall et al., 2007). R\&D does not only evaluate theory but mainly develops products that are effective in the implementation of learning(Gay, 1992).

There are four characteristics of $R \& D$, namely (1). The problems to be solved are those related to innovation or the application of technology in training; (2). Development, models, approaches, methods, media, and learning techniques to help achieve the competence of trainees; (3). Product development must pass expert tests, and field tests, and (4) The results of development, models, approaches, methods, media and learning techniques need to be neatly documented and reported in accordance with original research principles (Zuriyani, 2014). Meanwhile, the characteristics of R\&D according to Haviz (2016), namely, (1) the presence of intervention (intervention) when designing research objectives; (2) there is a cycle of analysis, design, and development, evaluation, and revision; (3) practitioner involvement, namely active participants from practitioners at every stage and research activity; (4) process-oriented which aims to understand and improve product quality; and (5) usability-oriented, namely improving the quality of the design with a practicalization process by users in the field, and sixth, theory-oriented, namely the design is carried out based on conceptual and theoretical frameworks, supported by an in-depth evaluation of the product.

$R \& D$ in education is a type of research that aims to produce products for learning that begins with needs analysis, product development, product evaluation, revision, and product dissemination (Zuriyani, 2014). R\&D is expected as an alternative in the midst of saturation with the type of Classroom Action Research or experiments/quasi-experiments that have occurred in recent years (Yuberti, 2014). R\&D in education is different from conventional research such as experiments, surveys and correlational analysis. Akker explains the difference between the two conventional research such as experiments, surveys and correlational analysis has a traditional approach and is focused on descriptive knowledge, so that it does not emphasize the practical aspect. While in development research, it is more focused on practical contributions and scientific contributions (Akker, 2007).

Research on R\&D is still very much needed (Editorial, 2021; Gustiani, 2019; Higher Education Research Group, 2021). Hanafi reviews the concept of R\&D in education which is broken down into five sub-focuses, namely (1) the characteristics of R\&D in education, (2) the steps of $R \& D$ in education, (3) research topics of $R \& D$ in education, (4) examples of $R \& D$ titles in education, and (5) systematic reports of $R \& D$ results in education (Hanafi, 2017). There are also those who study R\&D models in learning Islamic Religious Education in several aspects (Sa'diyah et al., 2020). Meanwhile, there is only one study in the form of an analysis of research trends in biological education/learning in Indonesia, which also reveals trends in R\&D (Ridho, 2018). The research was not focused on accredited journals, only looked at the percentage trend of the model used, did not analyze the consistency of the use of the model, and did not look at keywords that are generally used in relation to the world of education. Thus, it is still very rare or even rare for articles to focus on the trend of R\&D publications in Indonesia, especially in biological education. This SLR was aimed to analyze the trend of publications in the field of $R \& D$ in the journal of biological education in Indonesia (SINTA 2: 2017-2021). The results of this SLR will illustrate the condition of R\&D publications until 2021, both in terms of quantity, quality, and their respective contributions to educational institutions.

\section{METHOD}

\section{Study framework}

This study is SLR. SLR is a literature review method that identifying, assessing, and interpreting all research findings on a research topic to answer previously determined research questions (Aliyah \& Mulawarman, 2020). Through the SLR technique, we review 
and identify published articles systematically, which in each process follow standard (defined) steps (Siswanto, 2010; Triandini et al., 2019), to avoid bias and subjectivity (Jahan et al., 2016; Mengist et al., 2020; Pati \& Lorusso, 2017).

This systematic literature review adopts five-step guidelines from Denyer and Tranfield (2009), which is also reported to have been used by other authors, for example, Han et al. (2020), i.e. (1) Step 1: "Question formulation (Develop focus)"; (2) Step 2: "Locating Studies (Search for relevant studies)"; (3) "Study selection and evaluation (include and exclude articles using selection criteria"; (4) Step 4: "Analysis and Synthesis (Analyse and synthesis the selected articles)"; and (5) Step 5: "Reporting and using results (Summary of all studies)".

\section{Step 1: question formulation}

This step is to define the scope to develop a clear focus. This study proposes and attempts to address the following questions (from 2017 to 2021). This research question was made based on the needs of the selected topics, namely: RQ1: What is the trend of publication of JPBI, Biosfer JPB, and Bioedukatika for five years (2017-2021)? RQ2: What is the trend of types, number of published R\&D for 5 years (2017-2021), and how are the authors' consistency in following all stages of development according to the selected R\&D model? RQ3 What is the trend of keywords that are often used, and are they related to the theme of environmental education? RQ4: How do R\&D articles contribute to the education level?

\section{Step 2: locating studies}

This step is to locate, select, assess and list the core contributions related to the review questions. The target of this research is R\&D-type articles. This keyword is used to track related/appropriate articles published by three biology education journals in Indonesia accredited by the relevant ministry (as evidenced by the existence of a certificate as a SINTA 2 journal) until 2021. The search process uses the search menu at the journal's website address. JPBI (Jurnal Pendidikan Biologi Indonesia)-hereinafter referred to as "JPBI", Biosfe: Jurnal Pendidikan Biologi-hereinafter referred to as "Biosfer JPB" and Jurnal Bioedukatikahereinafter referred to as Bioedukatika. The data obtained is stored in PDF and *RIS formats, then synchronized into the Reference Manager (Mendeley). VOS-viewer software is used to visualize the data so that it is more clear and communicative.

\section{Step 3: study selection and evaluation}

This stage is carried out to ensure that the data obtained are appropriate for use in SLR studies or not. The study standards that meet the requirements are as follows: (1). The data used are from the last five years of publication (2017-2021); (2) articles published in English; (3) Full paper can be accessed; and (4) related to R\&D. Explicit selection criteria were applied for the inclusion and exclusion of relevant studies to maintain the transparency of the process (Figure 1). In the first phase, titles and abstracts of 379 articles were read in the first screening. These articles were published by JPBI, JPB Biosphere, and Bioedukatika from 2017-2021 and have been indexed in the SINTA database. In the second phase, we only use manuscripts published in English. All documents that did not meet the selection criteria were excluded; 305 articles remained for the next selection process (74 articles excluded). In the third phase, we only selected articles in the form of R\&D. We omitted other types of articles, so there are 56 articles (249 articles excluded). 


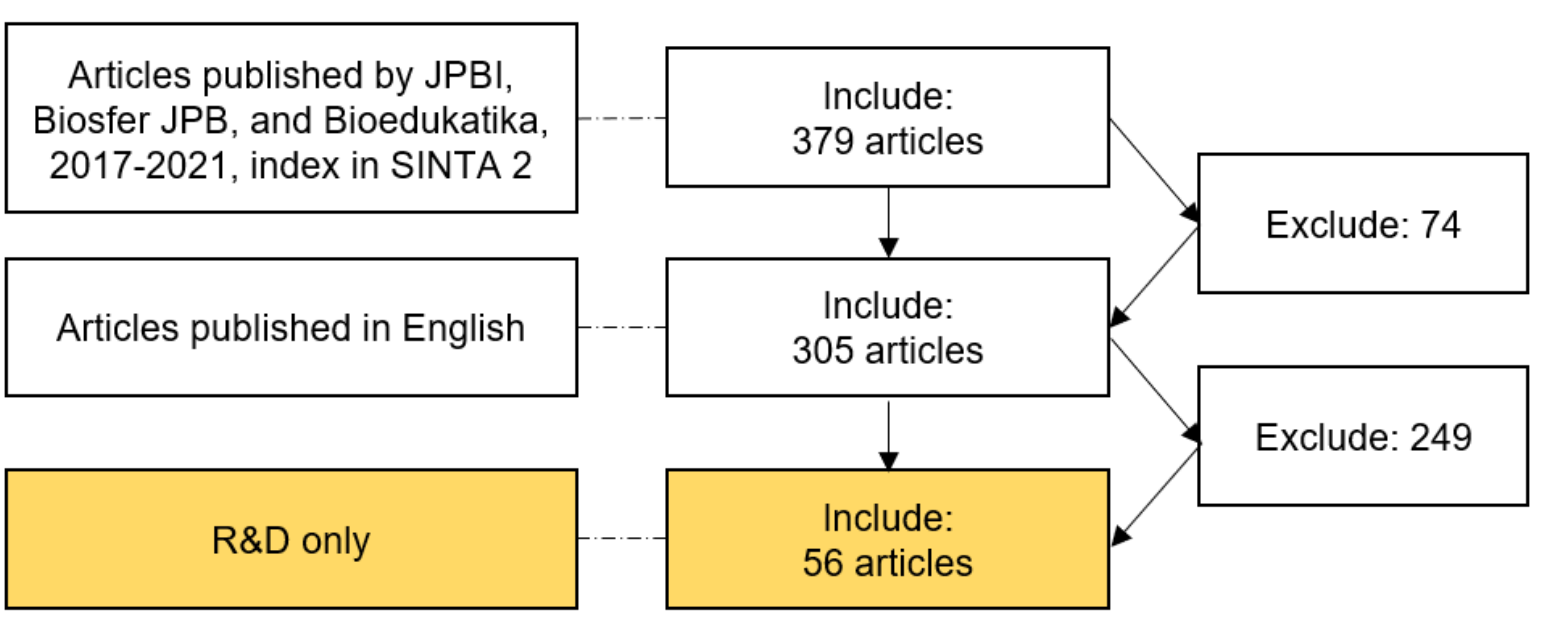

Figure 1. Review process for study selection

\section{RESULTS AND DISCUSSION \\ Publication trend of 2017-2021}

The publication trend (number of articles published) by JPBI, Biosfer JPB, and Bioedukatika in the last five years (2017-2021) is presented in Figure 2.

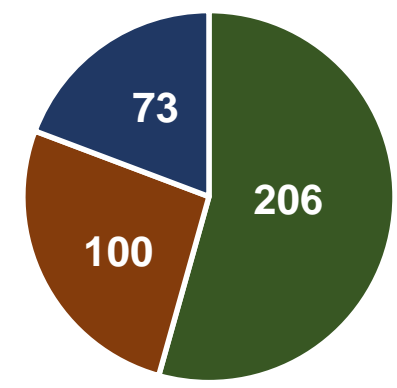

- JPBI - BIOSFER JPB - BIOEDUKATIKA

Figure 2. Number of articles published in 2017-2021

Based on Figure 2, it is known that in the last five years, there were 379 articles published by the three journals. JPBI published the most articles, with 206 articles. Meanwhile, Biosfer JPB published 100 articles, and Bioedukatika published 73 articles. JPBI publishes relatively consistent articles for each issue. There have been several changes to the number of articles, but the information is submitted in the "journal history". The purpose of the change is to improve quality. Biosfer JPB and Bioedukatika tend to be inconsistent regarding the number of articles published, sometimes more, sometimes less. These finding shows that the role of the editorial board or journal management is not good because it shows a lack of professionalism in managing the journal (not consistent as a publisher). According to RISTEK-BRIN (2020), a good journal will maintain the consistency of the writing standards that have been set. The role and cooperation of the editor team are necessary to maintain the consistency of publications. In addition, several things can be used to measure the performance of a journal, one of which is the Publication Output (Scholarly Output), concerning how much journal productivity is, how much impact or citation the journal gets, and how large the number of articles that the journal can publish. 


\section{Trends in the number, type, and consistency of the use of published R\&D models}

The number of R\&D articles published by JPBI, Biosfer JPB, and Bioedukatikais shown in Figure 3. Based on Figure 3, it is known that JPBI published 37 articles on R\&D during the last five years, while Biosfer JPB and Bioedukatika were 11 and 8, respectively. This shows a good contribution to the developof product of science and technology, that generated by R\&D.

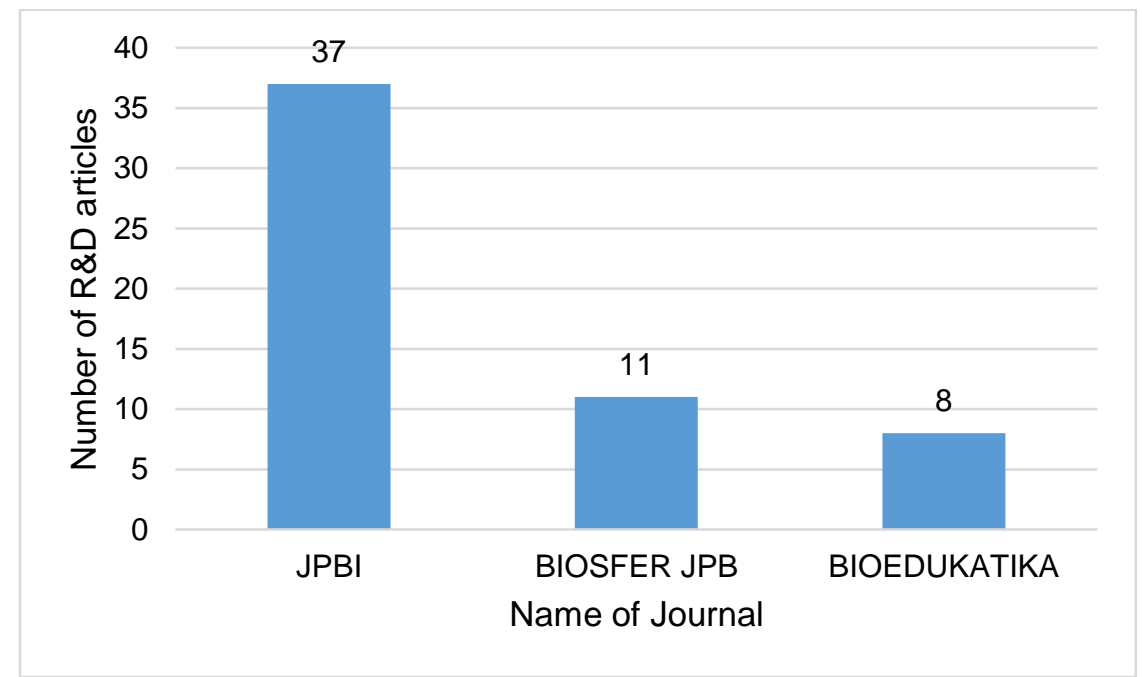

Figure 3. Number of published R\&D articles 2017-2021

Education and R\&D innovation are two activities that should always go hand in hand to ensure the progress of any country. Firstly, investing in knowledge and secondly turning this knowledge into greater welfare for society with the power of better products/outcomes and services at lower costs (Cosmen, 2013).

The trends in R\&D model used by the author and the consistency in implementing the model are presented in Table 1.

Table 1. Trends in the R\&D model used by the author and consistency in implementing the model

\begin{tabular}{clll}
\hline No & R\&D Model & Amount & \multicolumn{1}{c}{ References } \\
\hline 1 & 4D & 22 & (Abrori \& Adhani, 2017; Afandi et al., \\
& Thiagarajan & & 2019; Fajarianingtyas et al., 2019; \\
& & Firdaus et al., 2020; Hidayah et al., 2018; \\
& & Hidayati et al., 2019; Hidayati \& \\
& & Irmawati, 2019; Ikalindhari et al., 2020; \\
& & Indrata et al., 2020; Kamaludin et al., \\
& & 2018; Khastini et al., 2019; Kurniawan et \\
& & al., 2018; Patresia et al., 2020; Prihatin et \\
& & al., 2019; Primiani et al., 2020; Rahmi et \\
& & al., 2021; Retnowati et al., 2020; Ristanto \\
& & et al., 2018; Saniyyah et al., 2021; Sofia \\
& & et al., 2020; Widyaningrum \& Wijayanti, \\
& & 2018; Yuhana et al., 2020)
\end{tabular}

2 ADDIE $14 \quad$ (Aprilia \& Suryadarma, 2020; Arizen \& Suhartini, 2020; Hartono et al., 2021; Hayati \& Arifah, 2021; Indrata et al., 2020; Maulina et al., 2020; Mellisa \& Yanda, 2019; Qadariah et al., 2020;

\section{Description}

A total of 20 articles $(91 \%)$ did not fully use the development phase

A total of 4 articles $(29 \%)$ did not complete the development 


\begin{tabular}{|c|c|c|c|c|}
\hline No & R\&D Model & Amount & References & Description \\
\hline & & & $\begin{array}{l}\text { Sambodo et al., 2018; Sriyati et al., 2021; } \\
\text { Suciati \& Adian, 2018; Syah \& Yustina, } \\
\text { 2021; Yusnaeni et al., 2019; Yusuf et al., } \\
\text { 2017) }\end{array}$ & phase \\
\hline 3 & $\begin{array}{l}\text { Borg and } \\
\text { Gall }\end{array}$ & 10 & $\begin{array}{l}\text { (Abdullah, 2020; Andreas et al., 2019; } \\
\text { Handayani et al., 2020; Ilma et al., 2018; } \\
\text { Ilma \& Wijarini, 2017; Irwan et al., } \\
\text { 2019; Istiana et al., 2020; Ningsih et al., } \\
\text { 2019; Slamet et al., 2019; Widiansyah et } \\
\text { al., 2018) }\end{array}$ & $\begin{array}{l}\text { A total of } 8 \\
\text { articles }(80 \%) \\
\text { did not fully } \\
\text { use the } \\
\text { development } \\
\text { phase }\end{array}$ \\
\hline 4 & Sugiyono & 2 & (Zukmadini et al., 2018, 2020) & $\begin{array}{l}\text { A total of } 2 \\
\text { articles } \\
(100 \%) \text { did } \\
\text { not fully use } \\
\text { the } \\
\text { development } \\
\text { phase }\end{array}$ \\
\hline 5 & Plomp & 2 & $\begin{array}{l}\text { (Ali \& Arif, 2019; Syamsurizal et al., } \\
\text { 2021) }\end{array}$ & Concistent \\
\hline 6 & $\begin{array}{l}\text { Lee and } \\
\text { Owens } \\
\text { model }\end{array}$ & 2 & $\begin{array}{l}\text { (Darmawan et al., 2020; Kundariati \& } \\
\text { Rohman, 2020) }\end{array}$ & Concistent \\
\hline 7 & $\begin{array}{l}\text { Treagust } \\
\text { development }\end{array}$ & 1 & (Zulfia et al., 2019) & Concistent \\
\hline 8 & $3 \mathrm{E}$ model & 1 & (Ajizatunnisa et al., 2018) & Concistent \\
\hline 9 & $\begin{array}{l}\text { Richey and } \\
\text { Klein Model }\end{array}$ & 1 & (Maryuningsih et al., 2019) & Concistent \\
\hline
\end{tabular}

Based on Table 1, it is known that the authors use 9 models. The dominant one used is 4D Thiagarajan (Thiagarajan et al., 1974) a total of 22 articles (39\%), ADDIE (Branch, 2009) a total of 14 aticles $(25 \%)$, and Borg and Gall a total of 10 articles (18\%). The results of this study are in line with the results of Ridho (2018) which shows that the most significant development model used by researchers in research methods is the 4D Thiagarajan model with a percentage of $18 \%$ with a total of 97 articles, while from the results of content analysis that researchers do in the R\&D research method, many research models are not listed in the Paper Classification. Form (PCF) so that the results of the analysis show that other R\&D models show a fairly high percentage, namely $13.587 \%$ with a total of 75 articles, the Borg and Gall model with a percentage of $8 \%$ with a total of 44 articles, while the plomp model is the model in the most research method. little used by researchers in the field of biological education/learning in Indonesia with a percentage of $0.40 \%$ with a number of articles 2 of the total research methods analyzed.

The ADDIE model is also widely used. This is in line with Cahyadi (2019) that one of the R\&D designs that is often used is ADDIE. The ADDIE model is a system design model that shows the basic stages of the system that are easy to do. The ADDIE model is often used because the quality of the resulting product tends to be valid or quality. The development process requires several times of testing by a team of experts, individual research subjects, on 
a limited scale and on a wide scale (in the field) and revisions in order to improve the final product so that although the development procedure is shortened, it includes the process of testing and revision so that the product developed meets the good product criteria, empirically tested, and no more mistakes.

However, due to its linearity in several areas of education, the R\&D model by Borg and Gall has been applied and widely.. It serves as a model for R\&D in education at all levels. The ten steps defined by Borg and Gall are often modified by the authors, for no apparent reason. Several alternatives are also applied in education studies, but only a few are used as references (Gustiani, 2019).

Based on the study results that showed in Table 1 , it can be seen that, in general, from 56 articles, there are 34 articles (61\%) that do not consistently implement the stages of the R\&D model used. $91 \%$ of the authors using the Thiagarajan 4D model did not consistently follow each step, $29 \%$ of the authors using the ADDIE model did not consistently follow each step, and $80 \%$ of the authors who used the Borg and Gall model did not consistently follow each step.Based on this data, it can be said that many author(s) are inconsistent in following the steps that have been set. In Indonesia, there is a habit of authors who "cut" or "amputate" the model with unclear reasons. Some of them try to justify, but sometimes it shows that they are "lazy" or weak. Of course, this is a bad trend, especially since there is a tendency for other authors (especially novice authors) to imitate it. This is reasonable considering that the pattern is published in an accredited journal.

Some authors also use the model inconsistently. For example, an author says that he uses the ADDIE Model, but the references used are Dick and Carey. The ADDIE model and the Dick and Carey model are two different things. Dick \& Carey's instructional design model (the Systems Approach Model) is a nine or 10 step process for planning and designing effective learning initiatives (Dick et al., 2005). According to The World of Work Project (2019) this model does include all five stages of the ADDIE model, but it also adds further depth and structure. This model also focuses on design and less on implementation than the ADDIE model. The Dick and Carey model builds on iterative development through ongoing revision of instructions.

We can say that some articles experienced a poor article review process (lack of depth), both by reviewers and the editorial board. The review does not cover the essentials of R\&D which is related to the model they use. The author(s) 'habits' of mixing models should be recognized by reviewers/editors.

The next weakness is that the author(s) are not optimal in several ways, such as (1) not revealing the resulting product/model in relation to the related theories; (2) does not review the position of findings/products/models compared to similar ones that other researchers have produced; (3) there is no transfer of "what next" ideas based on unique findings, obstacles in implementing the R\&D model stages, or obstacles in this development research (which can be signs for future researchers).

\section{Trending frequently used keywords}

The trend of keywords that authors often use in their articles is presented in Figure 4. Based on Figure 4, it can be seen that the most used keyword is "Education". These keywords are often used in conjunction with several other keywords, such as biology, ecological concept, environmental education, atlas, biochemistry, archaebacteria, antimicrobials, local wisdom, Macromedia flash, human reproduction system, learning media, diversity, and posters. This shows that $\mathrm{R} \& \mathrm{D}$ has been widely used to develop products that support education. 


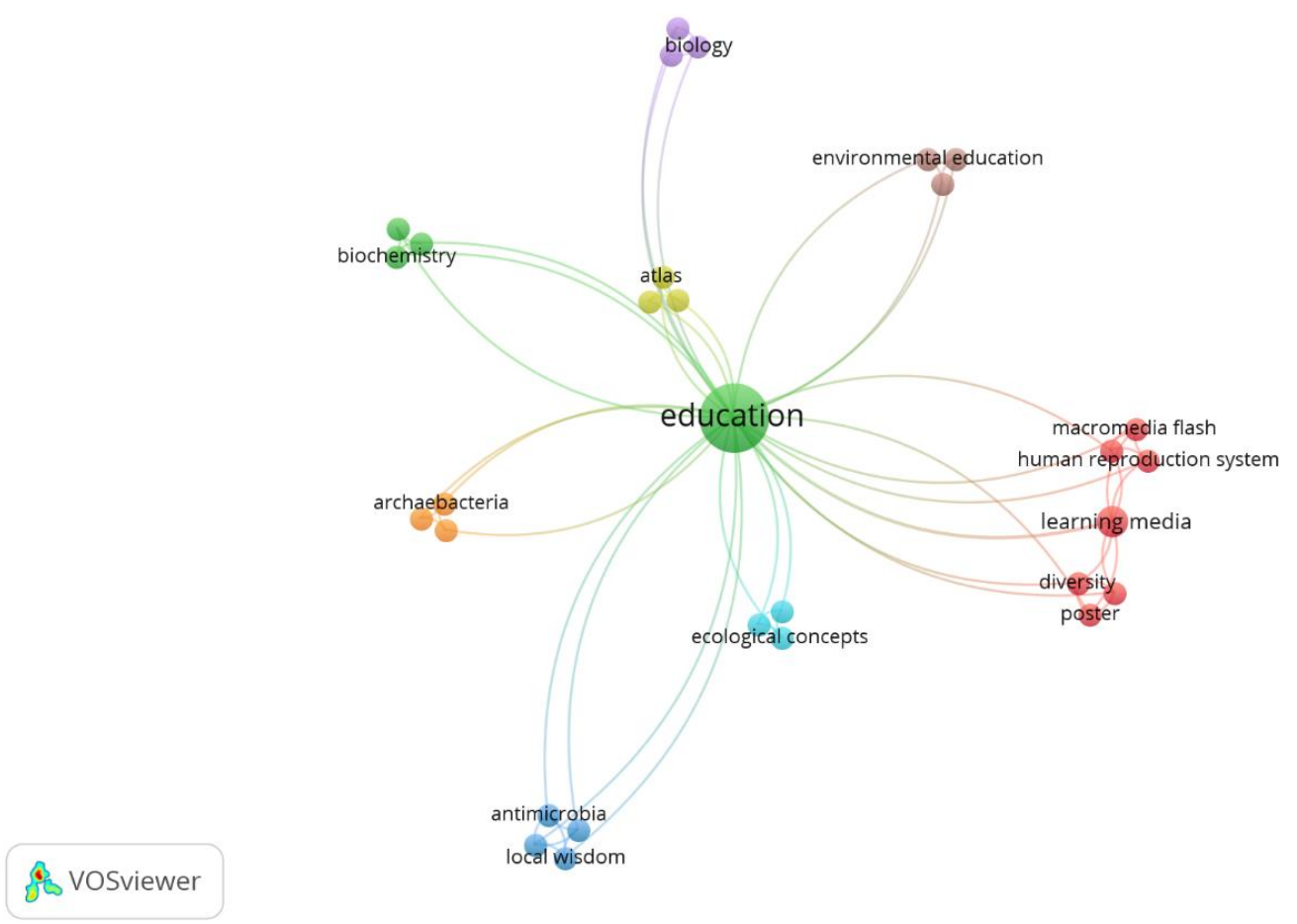

Figure 4. Trending keywords used in articles

$R \& D$ in education is a type of research that aims to produce products for learning that begins with needs analysis, product development, product evaluation, revision, and product dissemination or dissemination (Purnama, 2016). Through $\mathrm{R} \& \mathrm{D}$, problems that exist in education can be expressed, and solutions are sought. In addition, through $\mathrm{R} \& \mathrm{D}$, it is also possible to develop and apply new, more innovative things in education (Hanafi, 2017).

The use of R\&D will enrich existing research, and little by little, problems will be resolved (Purnama, 2016). Products produced through R\&D in the field of education (in the development of learning innovations) are expected to increase education productivity, namely graduates who are large in number, qualified, and relevant to the needs (Silalahi, 2017).

$\mathrm{R} \& \mathrm{D}$ is one of the six main areas of responsibility of teachers, which is frequent. As such, teachers play an important role in helping to realize the government's goal in education to increase access and use of high-quality products by teachers. Therefore, teachers are trained in understanding and implementing R\&D (Walker, 2017).

Like any other area of life, education also faces many challenges in this rapidly changing era. To overcome these challenges, development in the field of education is a must, which can be done as well as possible through research. R\&D activities can help develop existing curricula, tools, media, learning materials, teaching methodologies and techniques, and current assessment systems. R\&D leads to innovation that climed to becrucial element for the success of any educational institution. R\&D involves two main types of research based on objectives. It systematically combines basic and applied research and aims to find solutions to problems or create new educational products. It involves researching the market and student needs and developing new and better products and services to suit these needs (Gulzar, 2015).

\section{Contribution of Article R\&D for Education Level}

An overview of the contribution of $R \& D$ articles to the level of education, as presented in Table 2. Based on Table 2, it can be stated that the majority of R\&D carried out by experts is focused on high school and higher education, which are $45 \%$ and $40 \%$, respectively. Meanwhile, for junior high school level only $13 \%$, and elementary school only 
$2 \%$. This shows experts or researchers' high interest in developing educational products in high schools and universities. This condition demands the attention of the government, especially the ministry of education to support R\&D in educational institutions. According to (Hanafi, 2017), this is remembering that $R \& D$ in the education and social fields is still very small at less than $1 \%$ of the total cost of education. This is considered one of the main reasons why progress in the field of education has lagged slightly compared to other fields.

Table 2. Orientation educational level of users of the resulting product

\begin{tabular}{llll}
\hline No & Education level & Amount & Percentage (\%) \\
\hline 1 & Higher education & 22 & 40 \\
2 & Senior high school & 25 & 45 \\
3 & Junior high school & 7 & 13 \\
4 & Elementary school & 1 & 2 \\
\hline
\end{tabular}

One of the reasons why $R \& D$ is so important is that educational institutions are superior. R\&D enables educational institutions to collect data and information, use cuttingedge and useful technology, and then produce products or services for their consumers (Aliya, 2021), this includes students. R\&D is a process to develop new products or improve existing products. Products are not always in the form of hardware, such as books, modules, laboratory equipment, but also software, such as computer data processing programs, classroom learning, training, guidance, and evaluation (Putih, 2016).

Especially at the secondary school level, research in the field of curriculum implementation can be carried out by developing an educational product and seeking to discover new knowledge regarding fundamental phenomena and educational practices. Therefore, it is very appropriate to use the $R \& D$ method. The reason for using the $R \& D$ method in curriculum development research is to overcome the gap between the results of basic theoretical research and applied research that is practical. The product produced from this $R \& D$ can be in the form of hardware or software that has certain characteristics. These characteristics are a combination of a number of concepts, principles, assumptions, hypotheses, and procedures regarding something that has been found or resulted from basic research (Rosana, 2008).

\section{CONCLUSION}

Journals in the field of biology education that has been accredited at SINTA 2 level in the last five years have published a total of 379. JPBI has published the most articles, which is 206 articles. Specifically, in the field of R\&D, JPBI has published 37 articles on R\&D over the past 5 years, while Biosfer JPB and Bioedukatika are 11 and 8, respectively. This shows a good contribution, especially in terms of products. generated by R\&D. the authors use 9 models, and the dominant ones used are 4D Thiagarajan, ADDIE, and Borg \& Gall. In general, if we add up 56 articles, there are $61 \%$ articles that do not consistently carry out the stages or steps of the R\&D model used. The dominant keyword used is "Education". These keywords are often used in conjunction with several other keywords, such as biology, ecological concept, environmental education, atlas, biochemistry, archaebacteria, antimicrobials, local wisdom, macromedia flash, human reproduction system, learning media, diversity, and posters. This shows that R\&D has been widely used to develop products that support education. Most of the R\&D carried out by experts is focused on high school and college levels, which are $45 \%$ and $40 \%$ respectively. Meanwhile, for junior high school level only $13 \%$, and elementary school only $2 \%$.

\section{RECOMMENDATION}

This SLR has limitations, namely, this research is generally based on limited journals, namely only JPBI, Biosfer JPB, and Bioedukatika. In fact, there are several other educational 
journals, which, although they do not focus on biological education, may accept articles in biology education. Therefore, SLR focused on the R\&D aspect in educational journals is needed to further enrich the insights of readers and researchers interested in this field. This study is also focused on the journal SINTA 2. It is very possible that journals that still have a lower SINTA level but have been indexed by DOAJ (internationally) also publish articles on $\mathrm{R} \& \mathrm{D}$. Thus, a broader and comprehensive study is still needed.

\section{ACKNOWLEDGMENT}

Thank you very much to the Dean of Faculty of Teacher Training and Education (FTTE)-Universitas Muhammadiyah Malang (UMM) and the Director of Directorate Research and Community Service of UMM, who has assisted in this study, both morally and materially.

\section{REFERENCES}

Abdullah, Z. (2020). Development of STSE-based learning devices to improve the character of environmental care. Jurnal Bioedukatika, 8(2), 91 - 101. https://doi.org/10.26555/bioedukatika.v8i2.15304

Abrori, F. M., \& Adhani, A. (2017). Developing an atlas based on frond venation patterns analysis of polypodiales in Tarakan. JPBI (Jurnal Pendidikan Biologi Indonesia), 3(3), 222-237. https://doi.org/10.22219/jpbi.v3i3.4816

Afandi, A., Hidayat, S., \& Syahri, I. (2019). Developing interactive questions to measure the higher-order thinking skills of senior high schools' students. JPBI (Jurnal Pendidikan Biologi Indonesia), 5(2), 313-324. https://doi.org/10.22219/jpbi.v5i2.7747

Ajizatunnisa, A., Wahyuni, S., Waluyo, L., \& Miharja, F. J. (2018). Booklet development based on research identification of fiddler crab (Uca spp.) diversity in mangrove ecosystem. JPBI (Jurnal Pendidikan Biologi Indonesia), 4(1), 61-66. https://doi.org/10.22219/jpbi.v4i1.5337

Akker, J. Van Den. (2007). Curriculum Design Research. In T. Plomp \& N. Nieveen (Eds.), Proceedings of the seminar conducted at the East China Normal University, Shanghai $(P R \quad$ China) (pp. 37-50). Netzodruk Enschedea. http://www.slo.nl/downloads/2009/Introduction_20to_20education_20design_20researc h.pdf\#page $=39$

Ali, A., \& Arif, W. P. (2019). Developing Laboratory guidance of islamic science-integrated plant anatomy-physiology. Biosfer: Jurnal Pendidikan Biologi, 12(1), 70-82. https://doi.org/10.21009/biosferjpb.v12n1.70-82

Aliya, H. (2021). Research and Development_Pengertian dan Keuntungannya. Glints Blog.

Aliyah, U., \& Mulawarman, M. (2020). Kajian Systematic Literature Review (SLR) Untuk Mengidentifikasi Dampak Terorisme, Layanan Konseling dan Terapi Trauma Pada Anak-Anak. ISLAMIC COUNSELING Jurnal Bimbingan Konseling Islam, 4(2), 209222. https://doi.org/10.29240/jbk.v4i2.1759

Andreas, A., Situmorang, R. P., \& Hastuti, S. P. (2019). The development of learning songintegrated module based on flipped learning model to improve self-regulated learning and cognitive learning outcome of junior high school students. Jurnal Bioedukatika, 7(2), 97-106. https://doi.org/10.26555/bioedukatika.v7i2.12713

Aprilia, I., \& Suryadarma, I. G. P. (2020). E-module of mangrove ecosystem (emme): development, validation and effectiveness in improving students' self-regulated. Biosfer: Jurnal Pendidikan Biologi, 13(1), 114-129. https://doi.org/10.21009/biosferjpb.v13n1.114-129

Arizen, A., \& Suhartini, S. (2020). Mobile learning student worksheet based on socioscientific-issues: Enhancing students' scientific literacy skills in biology. JPBI (Jurnal 
Pendidikan Biologi Indonesia), 6(1), 15-24. https://doi.org/10.22219/jpbi.v6i1.11196

Borg, W. R., \& Gall, M. D. (1983). Educational research an introductioon. Longman.

Branch, R. M. (2009). Instructional design: The ADDIE approach (1st ed.). Springer US. https://doi.org/10.1007/978-0-387-09506-6

Cahyadi, R. A. H. (2019). Pengembangan Bahan Ajar Berbasis Addie Model. Halaqa: Islamic Education Journal, 3(1), 35-42. https://doi.org/10.21070/halaqa.v3i1.2124

Cosmen, J. (2013). Education and R\&D and innovation_two keys to development. GMV Innovating Solutions SL.

Darmawan, U., Redjeki, S., \& Widhorini, W. (2020). Interactive multimedia: Enhacing students' cognitive learning and creative thinking skill in Arthropod material. JPBI (Jurnal Pendidikan Biologi Indonesia), 6(2), 257-264. https://doi.org/10.22219/jpbi.v6i2.11370

Denyer, D., \& Tranfield, D. (2009). Producing a Systematic Review. In The SAGE Handbook of Organizational Research Methods (pp. 671-689). SAGE Publications Inc.

Dick, W., Carey, L., \& Carey, J. O. (2005). The systematic design of instruction (6th Ed.). Longman. http://www.hastudio.us/5_CV/thesystematicdesignofinstruction.pdf

Editorial. (2021). Indonesia's science super-agency must earn people's trust. Nature: The International Journal of Science, 597(September), 151-152.

Embedded Artistry. (2022). Research and Development (R\&D). https://embeddedartistry.com/fieldmanual-terms/research-and-development/

Fajarianingtyas, D. A., Akbar, N. A., \& Akbar, N. A. (2019). Cell as the system of life: student's worksheet development through scientific approach. Biosfer: Jurnal Pendidikan Biologi, 12(1), 109-121. https://doi.org/10.21009/biosferjpb.v12n1.109-121

Firdaus, F., Subchan, W., \& Narulita, E. (2020). Developing STEM-based TGT learning model to improve students' process skills. JPBI (Jurnal Pendidikan Biologi Indonesia), 6(3), 413-422. https://doi.org/10.22219/jpbi.v6i3.12249

Gall, M., Gall, J., \& Borg, R. (2007). Educational research: An introduction (8th Ed.). Pearson Education.

Gay, L. R. (1992). Education Research Competencies for Analysis and Application. Charles E. Milton Keynes Philadelphia Company.

Gay, L. R., Mills, G. E., \& Airasian, P. W. (2009). Educational research: Competencies for analysis and applications (9th Ed.). Prentice Hall.

Gulzar, A. A. (2015). Research and Development (R\&D). Educare. https://www.educarepk.com/research-and-development-rd.html

Gustiani, S. (2019). Research and Development (R \& D) Method as a Model Design in Educational Research and Its Alternative. Holistics Journal, 11(2), 12-22. https://jurnal.polsri.ac.id/index.php/holistic/article/view/1849/892

Han, Y., Chong, W. K., \& Li, D. (2020). A systematic literature review of the capabilities and performance metrics of supply chain resilience. International Journal of Production Research, 58(15), 4541-4566. https://doi.org/10.1080/00207543.2020.1785034

Hanafi, H. (2017). Konsep Penelitian R\&D Dalam Bidang Pendidikan. Jurnal Kajian Keislaman, 4(2), 129-150. http://www.aftanalisis.com

Handayani, R., Priyayi, D. F., \& Hastuti, S. P. (2020). The development of acrylic board game "Cytozzle" as a learning media on cells subject. Jurnal Bioedukatika, 8(3), 167 180. https://doi.org/10.26555/bioedukatika.v8i3.17231

Hartono, A., Tanjung, I. F., \& Syahputra, I. (2021). Virtual Laboratory of Andaliman Tissue Culture Integrated with Islamic values. Biosfer: Jurnal Pendidikan Biologi, 14(2), 285304. https://doi.org/10.21009/biosferjpb.20799

Haviz, M. (2016). Research and Development; Penelitian Di Bidang Kependidikan Yang Inovatif, Produktif Dan Bermakna. Ta'dib, 16(1), 28-43. 
https://doi.org/10.31958/jt.v16i1.235

Hayati, N., \& Arifah, L. (2021). A biodiverse entrepreneurship-based textbook: A media of students ' entrepreneurship enthusiasm development. JPBI (Jurnal Pendidikan Biologi Indonesia), 7(3), 248-257.

Hidayah, M. U., Lumowa, S. V. T., \& Boleng, D. T. (2018). Developing the archaebacteria and eubacteria web-based learning media for high school students. JPBI (Jurnal Pendidikan Biologi Indonesia), 4(2), 179-188. https://doi.org/10.22219/jpbi.v4i2.5750

Hidayat, C. (2018). Pengertian Penelitian Pengembangan Menurut Para Ahli, Tujuan Dan Ciri-Cirinya -. Ranah Research. https://ranahresearch.com/pengertian-penelitianpengembangan-menurut-ahli/

Hidayati, N., \& Irmawati, F. (2019). Developing digital multimedia of human anatomy and physiology material based on STEM education. JPBI (Jurnal Pendidikan Biologi Indonesia), 5(3), 497-510. https://doi.org/10.22219/jpbi.v5i3.8584

Hidayati, N., Pangestuti, A. A., \& Prayitno, T. A. (2019). Edmodo mobile: developing emodule on biology cell for online learning community. Biosfer: Jurnal Pendidikan Biologi, 12(1), 94-108. https://doi.org/10.21009/biosferjpb.v12n1.94-108

Higher Education Research Group. (2021). Ireland's Higher Education Research System. The Higher Education Research Group (HERG).

Ikalindhari, A., Ambarwati, R., \& Rahayu, D. A. (2020). Developing student worksheet based on iMindMap in animalia topic to train creative thinking ability. JPBI (Jurnal Pendidikan Biologi Indonesia), 6(3), 423-435. https://doi.org/10.22219/jpbi.v6i3.13235

Ilma, S., Superli, S., Zulfadli, Z., \& Rupa, D. (2018). Developing poster based on diversity of Nepenthes in Padat Karya forest, Krayan Nort Kalimantan. JPBI (Jurnal Pendidikan Biologi Indonesia), 4(1), 67-74. https://doi.org/10.22219/jpbi.v4i1.5231

Ilma, S., \& Wijarini, F. (2017). Developing of environmental education textbook based on local potencies. JPBI (Jurnal Pendidikan Biologi Indonesia), 3(3), 194-201. https://doi.org/10.22219/jpbi.v3i3.4540

Indrata, D. W., Adita, A., \& Nofiana, M. (2020). Science educational game: Increase procedural knowledge? Dimas. Jurnal Bioedukatika, 8(2), 79-90. https://doi.org/10.26555/bioedukatika.v8i3.15063

Irwan, I., Maridi, M., \& Dwiastuti, S. (2019). Developing guided inquiry-based ecosystem module to improve students' critical thinking skills. JPBI (Jurnal Pendidikan Biologi Indonesia), 5(1), 51-60. https://doi.org/10.22219/jpbi.v5i1.7287

Istiana, R., Herawati, D., \& Ardianto, D. (2020). Argumentation real-world inquiry to improve students' argumentation skill. Jurnal Bioedukatika, 8(2), 79-90. https://doi.org/10.26555/bioedukatika.v8i2.12705

Jahan, N., Naveed, S., Zeshan, M., \& Tahir, M. A. (2016). How to Conduct a Systematic Review: A Narrative Literature Review. Cureus, 8(11), e864-e864. https://doi.org/10.7759/cureus.864

Kamaludin, S., Surtikanti, H. K., \& Surakusumah, W. (2018). Developing issue-based teaching materials to improve student learning outcomes in Freshwater Biology course. Jurnal Pendidikan Biologi Indonesia, 4(2), 161-170. https://doi.org/10.22219/jpbi.v4i2.5549

Khastini, R. O., Wahyuni, I. W., Saraswati, I., Alimuddin, A., \& Nuangchalerm, P. (2019). Ethnobotanical study of medicinal plants utilized by the Baduy tribe used as a learning resource. JPBI (Jurnal Pendidikan Biologi Indonesia), 5(2), 197-206. https://doi.org/10.22219/jpbi.v5i2.7219

Kundariati, M., \& Rohman, F. (2020). Developing local-based invertebrates e-encyclopedia to improve scientific reasoning skills. JPBI (Jurnal Pendidikan Biologi Indonesia), 6(2), 189-198. https://doi.org/10.22219/jpbi.v6i2.11953 
Kurniawan, A. D., Muldayanti, N. D., \& Putri, B. E. (2018). Developing flash media of Quranic-based human reproduction system material. JPBI (Jurnal Pendidikan Biologi Indonesia), 4(3), 235-242. https://doi.org/10.22219/jpbi.v4i3.6822

Maryuningsih, Y., Hidayat, T., Riandi, R., \& Rustaman, N. (2019). Developing Gen-21cs on smartphone to cultivate the 21 st-century skills on biology teacher candidates. JPBI (Jurnal Pendidikan Biologi Indonesia), 5(3), 415-424. https://doi.org/10.22219/jpbi.v5i3.9714

Maulina, D., Priadi, M. A., Lengkana, D., Jalmo, T., Fauzisar, A. S., \& Amin, M. (2020). Book of insects' immune system: development and implementation with pbl in increasing students' learning outcome. Biosfer: Jurnal Pendidikan Biologi, 13(1), 4258. https://doi.org/10.21009/biosferjpb.v13n1.42-58

Mellisa, M., \& Yanda, Y. D. (2019). Developing audio-visual learning media based on video documentary on tissue culture explant of Dendrobium bigibbum. JPBI (Jurnal Pendidikan Biologi Indonesia), 5(3), 379-386. https://doi.org/10.22219/jpbi.v5i3.9993

Mengist, W., Soromessa, T., \& Legese, G. (2020). Method for conducting systematic literature review and meta-analysis for environmental science research. MethodsX, 7, 100777. https://doi.org/https://doi.org/10.1016/j.mex.2019.100777

Ningsih, L. R., Miarsyah, M., \& Rusdi, R. (2019). Interactive media of respiratory system material "resysmart" based on problem-based learning. JPBI (Jurnal Pendidikan Biologi Indonesia), 5(3), 459-470.

Pati, D., \& Lorusso, L. N. (2017). How to Write a Systematic Review of the Literature. HERD: Health Environments Research \& Design Journal, 11(1), 15-30. https://doi.org/10.1177/1937586717747384

Patresia, I., Silitonga, M., \& Ginting, A. (2020). Developing biology students' worksheet based on STEAM to empower science process skills. JPBI (Jurnal Pendidikan Biologi Indonesia), 6(1), 147-156. https://doi.org/10.22219/jpbi.v6i1.10225

Plomp, T. (2007). Educational Design Research: an Introduction. In T. Plomp \& N. Nieveen (Eds.), Proceedings of the seminar conducted at the East China Normal University, Shanghai (PR China),. Netzodruk Enschedea.

Prihatin, J., Naurah, N., \& Fikri, K. (2019). The development of organization of living things module through the use of mnemonic and mind mapping method using brain-based learning approach for junior high school natural science learning in coastal areas. Jurnal Bioedukatika, 7(2), 76-84. https://doi.org/10.26555/bioedukatika.v7i2.11132

Primiani, C. N., Prayitno, T. A., \& Dinka, E. (2020). Developing of fish anatomy learning module based on local wisdom in Ngebel Lake, Ponorogo, East Java. JPBI (Jurnal Pendidikan Biologi Indonesia), 6(2), 283-292. https://doi.org/10.22219/jpbi.v6i2.11813

Purnama, S. (2016). Metode Penelitian Dan Pengembangan (Pengenalan Untuk Mengembangkan Produk Pembelajaran Bahasa Arab). LITERASI (Jurnal Ilmu Pendidikan), 4(1), 19. https://doi.org/10.21927/literasi.2013.4(1).19-32

Putih, L. (2016). Konsep dan Pentingnya Penelitian dan Pengembangan. https://rasyidangkotasan.wordpress.com/2016/02/15/konsep-dan-pentingnya-penelitiandan-pengembangan/

Qadariah, N., Lestari, S. R., \& Rohman, F. (2020). Developing guided inquiry module in animal reproductive system material. JPBI (Jurnal Pendidikan Biologi Indonesia), 6(2), 305-316. https://doi.org/10.22219/jpbi.v6i2.12207

Rahmi, Y. L., Habibah, I. N., Zulyusri, Z., \& Darussyamsu, R. (2021). HOTS assessment in circulatory system learning: Validity, reliability, and item quality. JPBI (Jurnal Pendidikan Biologi Indonesia), 7(2), 171-178. https://doi.org/10.22219/jpbi.v7i2.15513

Retnowati, R., Awaludin, M. T., \& Heryawati, E. R. (2020). Developing an integrated biology module for students' environmental attitude instruments. JPBI (Jurnal 
Pendidikan Biologi Indonesia), 6(2), 327-334. https://doi.org/10.22219/jpbi.v6i2.11163

Richey, R. C., \& Klein, J. (2007). Design and Development Research: Methods, Strategies, and Issues. awrence Erlbaum Associates.

Ridho, M. (2018). Analisis tren penelitian dalam bidang pendidikan/pembelajaran biologi di indonesia. IAIN Batusangkar.

Ristanto, R. H., Zubaidah, S., Amin, M., \& Rohman, F. (2018). From a reader to a scientist: developing cirgi learning to empower scientific literacy and mastery of biology concept. Biosfer: Jurnal Pendidikan Biologi, 11(2), 89-99. https://doi.org/10.21009/biosferjpb.v11n2.90-100

RISTEK-BRIN. (2020). Panduan Editorial Pengelolaan Jurnal Ilmiah. In Direktorat Pengelolaan Kekayaan Intelektual Deputi Bidang Penguatan Riset dan Pengembangan Kementerian Riset Teknologi/ Badan Riset dan Inovasi Nasional. Kemenristek-BRIN. http://arjuna.ristekbrin.go.id/

Rosana, D. (2008). Peranan research and development (R\&D) dan Structural equation model (SEM) dalam penelitian pengembangan kurikulum tingkat satuan pendidikan. Cakrawala Pendidikan, 27(2), 175-189.

Sa'diyah, H., Alfiyah, H. Y., AR, Z. T., \& Nasaruddin, N. (2020). Model Research and Development dalam Pembelajaran Pendidikan Agama Islam. EL-BANAT: Jurnal Pemikiran Dan Pendidikan Islam, 10(1), 42-73. https://doi.org/10.54180/elbanat.2020.10.1.42-73

Sambodo, R. A., Prayitno, B. A., Karyanto, P., \& Sulistyowati, E. (2018). Developing mobile learning as ecology practical tool using three-layer observation framework. JPBI (Jurnal Pendidikan Biologi Indonesia), 4(3), 225-234. https://doi.org/10.22219/jpbi.v4i3.6810

Saniyyah, U. W., Hayati, N., \& Hidayat, S. (2021). Developing bacterial set box media containing fiqh al biah for Islamic senior high school. JPBI (Jurnal Pendidikan Biologi Indonesia), 7(1), 83-94. https://doi.org/10.22219/jpbi.v7i1.12944

Silalahi, A. (2017). Development Research (Penelitian Pengembangan) dan Research \& Development (Penelitian \& Pengembangan) dalam Bidang Pendidikan/Pembelajaran. Seminar \& Workshop Penelitian Disertasi Program Doktoral Pasca Sarjana Universitas Negeri Medan, 1-14. https://doi.org/10.13140/RG.2.2.13429.88803/1

Siswanto. (2010). Systematic Review Sebagai Metode Penelitian Untuk Mensintasis HasilHasil Penelitian (Sebuah Pengantar) (Systematic Review as a Research Method to Synthesize Research Results (An Introduction)). Buletin Penelitian Sistem Kesehatan, 13(4), 326-333.

Slamet, A., Taharu, F. I., \& Hudha, A. M. (2019). Developing genetic learning module based on blue eyes phenomenon in Buton Island, Southeast Sulawesi. JPBI (Jurnal Pendidikan Biologi Indonesia), 5(1), 69-76. https://doi.org/10.22219/jpbi.v5i1.7071

Sofia, H. W., Utomo, A. P., Hariyadi, S., Wahono, B., \& Narulita, E. (2020). The validity and effectivity of learning using STEAM module with biotechnology game. JPBI (Jurnal Pendidikan Biologi Indonesia), 6(1), 91-100. https://doi.org/10.22219/jpbi.v6i1.10979

Sriyati, S., Septiani, F., Udayani, K. S. H., \& Amprasto, A. (2021). Local wisdom-based teaching materials to improve student problem-solving. Jurnal Bioedukatika, 9(2), 111123. https://doi.org/10.26555/bioedukatika.v9i2.17951

Suciati, A., \& Adian, T. (2018). Developing the fun and educative module in plant morphology and anatomy learning for tenth graders. JPBI (Jurnal Pendidikan Biologi Indonesia), 4(1), 53-60. https://doi.org/10.22219/jpbi.v4i1.5334

Syah, F., \& Yustina, Y. (2021). Developing biology enrichment book of fish diversity of aquatic ecosystems in Kampar District. JPBI (Jurnal Pendidikan Biologi Indonesia), 7(2), 188-197. https://doi.org/10.22219/jpbi.v7i2.13439

Syamsurizal, S., Syarif, E. A., Rahmawati, R., \& Farma, S. A. (2021). Developing human 
movement system booklet as a biology teaching material suplement for XI grade students. JPBI (Jurnal Pendidikan Biologi Indonesia), 7(1), 95-103. https://doi.org/10.22219/jpbi.v7i1.12828

The World of Work Project. (2019). The Dick and Carey Instructional Design Model. https://worldofwork.io/2019/08/dick-carey-instructional-design-model/

Thiagarajan, S., Semmel, D. S., \& Semmel, M. I. (1974). Instructional development for training teachers of exceptional children: A sourcebook. Center for Innovation in Teaching the The Handicappaed \& Indiana University. https://files.eric.ed.gov/fulltext/ED090725.pdf

Triandini, E., Jayanatha, S., Indrawan, A., Werla Putra, G., \& Iswara, B. (2019). Metode Systematic Literature Review untuk Identifikasi Platform dan Metode Pengembangan Sistem Informasi di Indonesia. Indonesian Journal of Information Systems, 1(2), 63. https://doi.org/10.24002/ijis.v1i2.1916

Walker, M. (2017). Insights into the Role of Research and Development in Teaching Schools National Foundation for Educational Research (NFER) Insights into the Role of Research and Development in Teaching Schools.

Widiansyah, A. T., Indriwati, S. E., Munzil, M., \& Fauzi, A. (2018). I-invertebrata as an android-based learning media for molluscs, arthropods, and echinoderms identification and its influence on students' motivation. JPBI (Jurnal Pendidikan Biologi Indonesia), 4(1), 43-52. https://doi.org/10.22219/jpbi.v4i1.5476 43

Widyaningrum, D. A., \& Wijayanti, T. (2018). Developing of guided inquiry-based biochemistry practicum guidebook. JPBI (Jurnal Pendidikan Biologi Indonesia), 4(3), 209-214. https://doi.org/10.22219/jpbi.v4i3.6857

Yuberti, Y. (2014). "Penelitian Dan Pengembangan" Yang Belum Diminati Dan Perspektifnya. Jurnal Ilmiah Pendidikan Fisika Al-Biruni, 3(2), 1-15.

Yuhana, Y., Maridi, M., \& Dwiastuti, S. (2020). Inquiry-Learning-Based module: Improving students' critical thinking skills in anatomy structure and bacteria physiology materials. JPBI (Jurnal Pendidikan Biologi Indonesia), 6(2), 341-346. https://doi.org/10.22219/jpbi.v6i2.11026

Yusnaeni, Y., Lika, A. G., \& Hiul, S. (2019). Designing student worksheet in human respiratory system based on inquiry to promote 21st-century skills. Biosfer: Jurnal Pendidikan Biologi, 12(1), 34-44. https://doi.org/10.21009/biosferjpb.v12n1.34-44

Yusuf, M. M., Amin, M., \& Nugrahaningsih, N. (2017). Developing of instructional mediabased animation video on enzyme and metabolism material. JPBI (Jurnal Pendidikan Biologi Indonesia), 3(3), 254-257. https://doi.org/10.22219/jpbi.v3i3.4744

Zukmadini, A. Y., Jumiarni, D., \& Kasrina, K. (2018). Developing antimicrobial medicinal plants pocketbook based on local wisdom of Muko-Muko and Serawai ethnics. JPBI (Jurnal Pendidikan Biologi Indonesia), 4(2), 95-104. https://doi.org/10.22219/jpbi.v4i2.5436

Zukmadini, A. Y., Kasrina, K., Jumiarni, D., \& Rochman, S. (2020). Pocketbook based on local wisdom and its effectivity in improving students' knowledge on the utilization of traditional medicine plants. Biosfer: Jurnal Pendidikan Biologi, 13(1), 59-74. https://doi.org/10.21009/biosferjpb.v13n1.59-74

Zulfia, F. A., Susilo, H., \& Listyorini, D. (2019). Virus-bacteria diagnostic test (vbd-test) in identifying biology teacher's misconception. Biosfer: Jurnal Pendidikan Biologi, 12(2), 144-156. https://doi.org/10.21009/biosferjpb.v12n2.144-156

Zuriyani, E. (2014). Penelitian Research and Development $(R \&$ \&): Alternatif Pengembangan Profesi. BDK Palembang. https://bdkpalembang.kemenag.go.id/upload/files/1. Website elsy April.pdf 